\title{
Practical visioning for the decade of austerity
}

\author{
By Carol Hughes and William Pfannenstiel
}

\section{The ACRL environmental scan}

( ne of the charges of the ACRL Planning Committee is to prepare an environmental scan for the organization and its members as part of the effort to bring the ACRL Plan into sharper focus. In the CERL News for September 1989, Ann E. Prentice authored the first ACRL scan article compiling data on trends pertinent to higher education from a variety of excellent sources. This article updates Prentice's work, expanding it somewhat to encompass trends explicitly of interest to professional associations such as ACRL.

\section{Environmental scanning}

The purpose of environmental scanning is that of "linking external issues, events, and trends with planned change."1 Most institutions of higher education have a formal plan with a mission statement, goals, and objectives. The plan often represents a statement of what the institution wants to become and an indication of the strategies which will be undertaken to achieve the vision. Environmental scanning is a process that identifies trends in the external environment that might provide opportunities for devising new strategies or warn of threats to the institution's ability to implement its chosen strategies and achieve its goals.

Environmental scanning allows planning to become a dynamic process that adjusts to changes in society as they occur. It avoids the problems that occur when planning is performed as a process that merely extrapolates the future based entirely on the past. Evaluat- ing a plan in light of environmental trends also precludes treating institutional goals as an idealized list of wishes, unrelated to an institution's ability to achieve them.

The process of scanning involves gathering data, identifying trends, and analyzing them to assess the degree of impact each trend might have on the institution's ability to achieve its goals. The data gathering process can involve various methodologies from statistical analysis of data to content analysis of newspaper and journal articles. It is important to base trend analyses on hard data rather than merely on published opinion to enable managers to distinguish trends from fads.

However, as Prentice noted in her 1989 report to the Planning Committee, ACRL does not have the apparatus and resources needed to organize and conduct a full-blown, ongoing data-gathering and forecasting process. Therefore this article follows the precedent of the earlier one in summarizing trends and conclusions that other environmental scanners and professional leaders have noted.

In this update we present trends that are of importance to professional associations in general, as well as to institutions of higher education. In this way we hope to call attention to how the environment might affect ACRL itself as well as the institutions that employ its members. We have also attempted to indicate trends that impact colleges as well as research universities. It is not always the case that colleges experience opportunities and threats from the environment in the same way they are experienced by research institutions. Hopefully, future scans will be able to enhance analysis of the ways in which college and university environments differ and make the environmental 
scan useful to the greatest possible number of ACRL members.

The process of generating an environmental scan will be useful to ACRL only if its members and officers use it to evaluate the impact that these trends might have on their own institution's plan, the ACRL plan, and member activities. Since the trends will affect the various goals of each ACRL member institution, committee, and section differently, no interpretation of the impacts is offered herein by the authors.

\section{Trends in higher education of significance for academic libraries}

This list of trends is focused on a three-year horizon since the ACRL Planning Committee will be revising the scan again in the near future. Many of the trends noted earlier by Prentice are still affecting the world of higher education in 1992. Therefore the following list of trends incorporates several items from the 1989 list.

\section{Economics}

- A weak, somewhat volatile dollar in the international market;

- Increasing costs of information resources above the low rate of inflation, although col- lege libraries will be affected less adversely than research institutions;

- Costs of telecommunications will remain relatively stable;

- Deferred capital investments and maintenance costs will require significantly increased attention, especially on older campuses;

- Private sources of revenue will comprise a larger proportion of funding for institutions, especially for large research institutions;

- Major cost-cutting efforts will be instituted throughout universities and colleges. Libraries will be pressed to maintain their present share of the institutional budget; and

- Government funding will not increase and limited resources will continue to hamper growth.

\section{Politics}

- Questions of ownership of intellectual property will increase;

- Continued pressure to regulate access to information and continued debate over public access to information;

- Increased public scrutiny and governmental oversight of higher education which will especially affect operations at research institutions; and

- Global competitiveness will increase as
Women \& Literature/New Scholasticism; a Quarterly Review of Philosophy/Zeitschrift für volkskunde/Theatre Arts/Labor Law Journal/Revue historique/Royal Society of Arts, London Journal/Greece \& Rome/Shakespeare Quarterly/ELH; a Journal of English Literary History/Anthropological Quarterly/Stanford Law Review/American Economic Review/ Czechoslovak Review/Romania/Propaganda Analysis/Victoria Magazine/War Medicine/ Modern Philology/Economist/Commentary; a Jewish Review/Hispanic Review/Frontiers of Democracy/World Today/American Farmer/ Race/Anthropological Review/Constitutional Review/Quill/Anti-Slavery Record/Library Journal/Critical Review of Theological and PhilosophicalLiterature/American Suffragette/ Correct English/Annals of Botany/American Journal of Psychology/History of Education Journal/Neophilologus; a Modern Language Quarterly/Slavonicand East European Review/ Interracial Review/British Life and Thought/ Romance Philology/Mediaeval \& Renaissance Studies/Medical Times/International Journal of Ethics/Scrittori d'Italia/Social Casework/ Anti-Slavery Record/Southern Indian Studies/ Negro Music Journal/Theologische revue/ Cambridge Review/Garden and Forest/Railway Age/National Geographic Magazine

\section{Cumulative Contents Index}

Electronic searching has already revolutionized your access to current journals.

\section{CCI now brings you the backfiles!}

Immediate electronic access to over one million article citations supports both graduate and undergraduate research. Broad coverage facilitates interdisciplinary searching never before possible.

Keyword and Boolean searches will quickly locate relevant article citations and their corresponding table-of-contents pages.

To receive a working list of the $3,000+$ journals included in CCI, please call toll-free 800-752-0515.

Chadwyck-Healey Inc. 
will efforts at protectionism. Information and higher education will be seen as an important competitive edge in the world economy.

\section{Demographics}

- Regional variations in demographic patterns will result in some areas of the country experiencing a decline in both student and employee pools and in their tax base while other regions will experience growth;

- Greater emphasis on life-long learning opportunities for nontraditional students within higher education. The private sector will become a major adult education provider;

- Access to higher education will continue to be problematic for members of minority groups;

- Greater numbers of women and minorities in the workforce;

- A shortage of faculty in some disciplines will become evident and competition for new and minority faculty will increase; and

- Increased emphasis on the undergraduate educational experience at research institutions, with increased attention to the needs of underprepared students. Community colleges will assume a larger role as "feeder" schools.

\section{Scholarly communication}

- Published scholarship will continue to grow in quantity;

- Increased use of electronic communication by faculty and students in scholarship and teaching;

- Increased emphasis on research partnerships with private industry; and

- Global focus of research will grow stronger.

\section{Information technology}

- Progress toward electronic publishing will be hampered by concerns for intellectual property rights;

- Computing environments will become increasingly diverse in hardware, software, and infrastructure configurations;

- Technology will continue to change faster than organizations and human patterns of information exchange can accommodate. Expectations for cost savings from the implementation of technology will not be greatly realized;

- Costs of rapid obsolescence of technology will complicate pressures for greatly expanded reinvestment;

- New formats of information will continue to proliferate. However, the gap between the technology "haves" and "have-nots" will widen with continued budget constraints;

- College libraries will take over responsibilities for local audiovisual services as faculty increase their use of these technologies; and

- Emphasis on multimedia products will grow.

\section{Education for the information profes- sions}

- New educational needs produced by an increased knowledge base in information science and technology will build pressures for curriculum revision and longer programs. "Sea changes," "re-inventing," and "re-engineering" will be watchwords;

- Schools whose faculty adopt an active role and a visible research presence within the university will grow stronger;

- Master's programs that include an internship or practicum will become more available; and

- An increased interest in providing undergraduate education on information issues will be apparent.

\section{Libraries}

- The quality revolution in society and higher education will intensify. Libraries will be asked to define quality in their services;

- Creative ideas for enhancing external support will be increasingly important;

- Managing a culturally diverse organization will present continuing challenges;

- Access will not replace ownership in the near term. New technologies and services from the private sector will become more important in the local strategy for providing full-text. Increased dependency on remote collections will create pressures for the redesign and strengthening of all types of resource-sharing agreements;

- Print format will continue to dominate local collections. Space issues will continue to be critical at many institutions;

- Staff training and development will require increased resources as technological innovations occur and library operations are redesigned;

- An aging workforce limits opportunities for promotion within many organizations; and

- Service demands and pressure for providing individualized and convenient information services to users grows. 


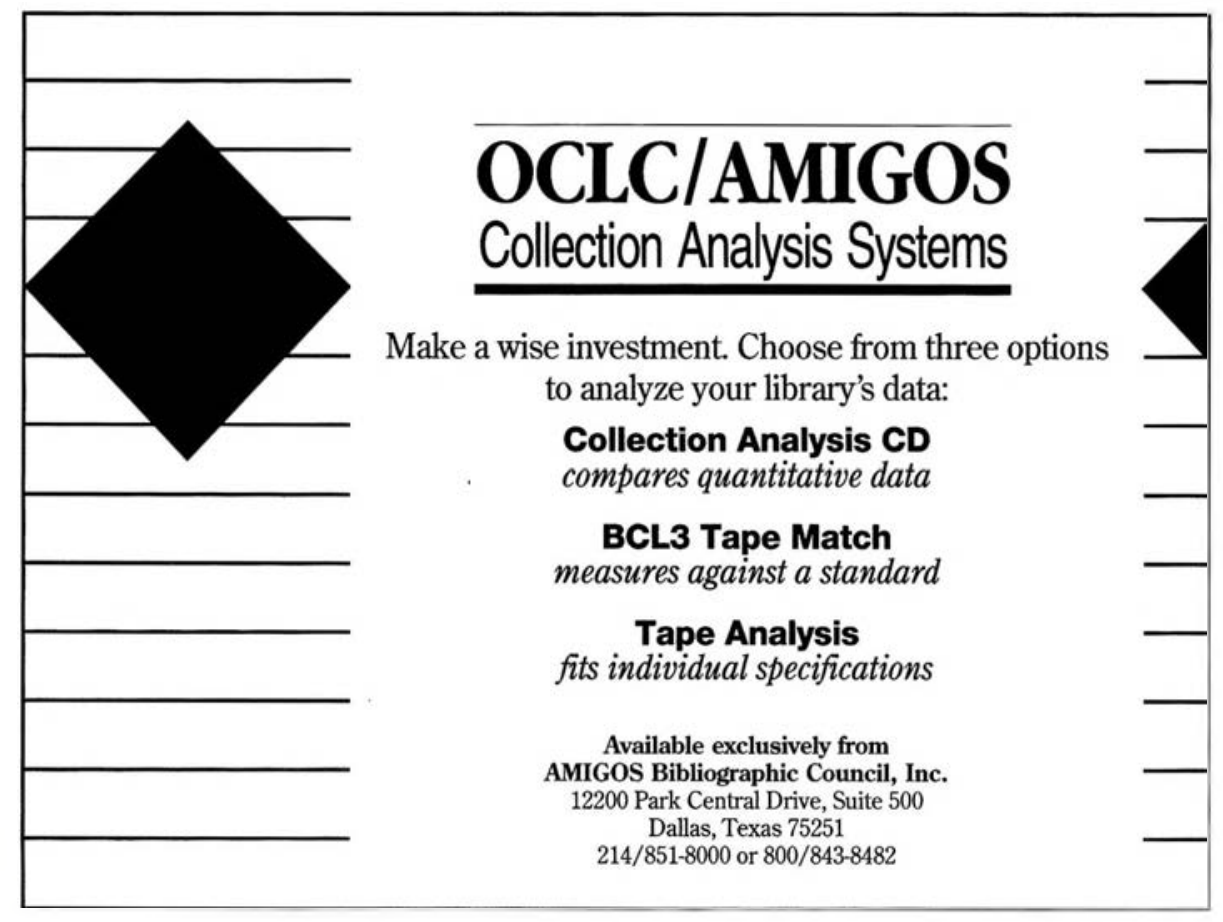

\section{Professional association trends}

- Probable decline in volunteerism;

- Travel budgets continue to be tight at many institutions as travel costs increase;

- The need for knowing and responding to the needs and desires of one's membership will increase;

- Pressures for regionalization and specialization continue to compete with national associations; and

- A decline in the economy presents members and associations with increasing monetary pressures.

The future implied by these trends is one of change and challenge for our association, the profession, and for the institutions in which we are employed. However, the next and the most important step to take is that of careful interpretation of these trends and an evaluation of their degree of impact on the organization. After such an analysis is made, it will be possible to adjust to the new demands of the environment and ensure that the desired goals are still within grasp.

\section{Notes}

${ }^{1}$ Bruce A. Montgomery and Martha A. Hesse, "Environmental scanning and external tenden- cies in higher education," Planning for Higher Education 18:4 (1989-90): 61-101.

\section{Bibliography}

ACRL FY1993 Budget Impact Statement (Chicago: ALA, 1992).

Change Drivers; An Update to What Lies Abead; Countdown to the 21st Century (Alexandria, Va.: United Way Strategic Institute, 1991).

Chronicle of Higher Education 38 (1991/92).

Journey to the 21st Century; A Summary of OCLC's Strategic Plan (Dublin, Ohio: OCLC, 1991).

Richard N. Katz and Richard P. West, Sustaining Excellence in the 21st Century: $\mathrm{A} V \mathrm{Vi}$ sion and Strategies for College and University Administration (Boulder, Colo.: CAUSE, 1992).

G. Gregory Lozier and Deborah J. Teeter, "Strategic Planning and Total Quality Management," in Total Quality Management in Higher Education (San Francisco: Jossey-Bass, 1991).

Bruce A. Montgomery and Martha L. Hesse, "Environmental scanning and external tendencies affecting American higher education," Planning for Higher Education 18(4) (1989-90): 61102.

(Scan cont. on page 28) 
eign \& International Documents Librarian/African \& Middle Eastern Bibliographer, Stanford University Libraries, Stanford, CA 94305-6100; Gretchen E. Holten, Humanities/Social Sciences Bibliographer, University of Nebraska-Lincoln, 216N Love Library, Lincoln, NE 68588-0410.

\section{Women's Studies Section (WSS)}

Vice-Chair/Chair-Elect: Cyntbia S. Faries, Reference Librarian, Penn State University, E108 Pattee Library, University Park, PA 16802; Lori A. Goetsch, Head, Information/Reference, Michigan State University Libraries, East Lansing, MI 48824-1048.
Secretary: Thura Reed Mack, Reference Librarian, University of Tennessee, Knoxville, TN 37996-1000; Grace M. Jackson-Brown, AfroAmerican Studies Subject Specialist and Branch Head Librarian of the Black Culture Center Library, Indiana University-Bloomington, Black Culture Center Library, 109 N. Jordan Ave., Bloomington, IN 47405.

Member-at-Large: Mila C. Su, Senior Assistant Librarian-Reference, Robert E. Eiche Library, Penn State Altoona Campus, Altoona, PA 16001; Kristin H. Gerbard, Authorities Coordinator and Monographic Cataloger, Iowa State University, 204 Parks Library, Ames, IA 50011.

\section{(Scan cont. from page 24)}

James L. Morrison, "Establishing an environmental scanning/forecasting system to augment college and university planning," Planning for Higher Education 15(1) (1987): 7-22.

Mark Sandler, "Dollar watch: 1991 year-end update," Library Lssues 12(3) (January 1992): 2-3.

Mimi Harris Steadman and Ralph A. Wolff, Evaluating Library Quality in the Accreditation Process: What Changes Do New Technologies Bring? Unpublished discussion paper for the Accrediting Commission for Senior Colleges and Universities and the WASC Presidents' Forum, 1991.

Marvin J. Cetron and Owen Davies, "Fifty trends shaping the world," The Futurist 25(5) (September-October 1991): 12-21.
Visions Listserv postings, 4/92-6/92.

The Winds of Change: Key Trends Impacting Associations in the '90s. Unpublished 1991 draft prepared by the American Society of Association Executives.

Strategic Planning Documents from various university libraries were also consulted and many conversations with library educators were held. A special thanks to all the institutions who responded to William Pfannenstiel's survey updating the ACRL Environmental Scan.

Autbors'note: We would like to thank all the members of the ACRL Planning Committee for assistance provided in preparing this scan.

\section{Operate an ERIC clearinghouse}

The U. S. Department of Education announces a competition (Request for Proposals-RFP) for the award of 16 contracts to operate Educational Resources Information Center (ERIC) Clearinghouses.

Located around the country, the 16 ERIC Clearinghouses-the subject of this RFP-are each responsible for acquiring, processing, synthesizing, and disseminating information about particular aspects or subject areas of education. Established in 1966, ERIC is a national information network designed to provide users with ready access to education materials.

A separate contract will be issued for each ERIC Clearinghouse, as follows: Adult, Career, and Vocational Education; Assessment and Evaluation, Community Colleges; Counseling and Student Services, Disabilities and Gifted Education; Educational Management; Elementary and Early Childhood Education; Higher Education; Information Resources; Languages and Linguistics; Reading and Communication Skills; Rural Education and Small Schools; Science, Mathematics, and Environmental Education; Social Studies/Social Science Education; Teaching and Teaching Education; and Urban Education.

Proposals are due January 29, 1993. Send proposals to: LaTonya D. Simpson, Grants and Contracts Service, GSA Building, Room 3633, 7 th and D Streets, SW, Washington, D.C. 20202; phone: (202) 708-8191. 